by Xuexin Yan ${ }^{1,2}$, Yan Xu ${ }^{1,2 *}$, Tianliang Yang ${ }^{1,2 *}$, Luigi Tosi ${ }^{3}$, Esther Stouthamer ${ }^{4}$, Philip Minderhoud ${ }^{4,5,6}$, Pietro Teatini ${ }^{5}$, Henk Kooi ${ }^{6}$, Heri Andreas ${ }^{7}$, Dhota Pradipta ${ }^{7}$, Sandra Donnici $i^{3}$ and Roberta Boni $i^{8}$

\title{
Sustainable development of coastal cities through control of land subsidence: activities of IGCP Project 663 in Jakarta
}

\author{
${ }^{1}$ Shanghai Institute of Geological Survey, Shanghai 200072, China; *Corresponding author, E-mail: xuyan@sigs.com.cn \\ ${ }^{2}$ Key Laboratory of Land Subsidence Monitoring and Prevention, Ministry of Natural Resources, Shanghai 200072, China \\ ${ }^{3}$ Institute of Geosciences and Earth Resources, National Research Council, Via G. Gradenigo, 6, 35131 Padova, Italy \\ ${ }^{4}$ Department of Physical Geography, Utrecht University, Princetonlaan 8A, 3508 CB Utrecht, Netherlands \\ ${ }^{5}$ Department of Civil, Environmental and Architectural Engineering, University of Padova, Padova, 35131, Italy \\ ${ }^{6}$ Deltares Research Institute, Daltonlaan 600, 3584 BK Utrecht, Netherlands \\ ${ }^{7}$ Geodesy Research Division, Institute of Technology Bandung, Bandung 40132, Indonesia \\ ${ }^{8}$ Earth \& Environmental Sciences Department, University of Pavia, Pavia, 27100, Italy
}

(Received: May 24, 2021; Revised accepted: June 22, 2021)

https://doi.org/10.18814/epiiugs/2021/021014

The awareness on the importance that land subsidence plays on coastal processes at the regional scale is increased over the last two decades, and it clearly appears that land subsidence can contribute primarily to the relative sea level rise affecting coastal zones. Jakarta is one of the cities mostly affected by the combination of sea-level rise and land subsidence. In this paper, the activities carried out in Jakarta under the umbrella of the IGCP Project 663 were presented, and the possible measures and best practices mitigating land subsidence for the research associates and potential stakeholders were provided, with which can serve as inspiration for authorities and communities facing land subsidence. Meanwhile, major achievements of IGCP 663 in Jakarta were summarized and introduced, including dissemination session, scientific session and field trips. Specifically, major advances on coastal subsidence studies regarding the effect of relative sea level rise, subsidence mapping, monitoring and simulation, as well as the support of policy making are highlighted and summarized.

\section{Introduction}

The IGCP Project 663 (Impact, Mechanism, Monitoring of Land Subsidence in Coastal cities - IM2LSC) is a scientific cooperative program between institutions and researchers to develop better understanding of land subsidence at international level (Yan et al., 2020), and its second international workshop was held from September 17 to 21, 2019 in Jakarta, Indonesia, which included dissemination and scientific activities. Nearly 100 members of the IGCP 663 project teams and representatives of UNESCO Land Subsidence International Initiative (LaSII) from China, Italy, the Netherlands, Indonesia, Thailand,
Vietnam and Pakistan attended the workshop, among which over $90 \%$ were from developing countries.

This workshop arranged a roundtable meeting, annual work report, keynote lectures, oral and poster presentations by young professionals, technical teaching and training, field trips, etc. The Indonesian government held an official ceremony for the release of the "Road map for prevention and control of land subsidence in the coastal lowland of Indonesia". The vice-president of the UNESCO LaSII, Pietro Teatini, addressed the conference and gave a keynote lecture.

After the meeting, a field trip was organized in Jakarta, and four sites seriously affected by land subsidence were investigated.

\section{Dissemination Session}

Low-lying coastlands generally encompass a variety of environments, such as farmlands, estuaries, deltas, lagoons and urbanized areas including valuable ecosystems, historical heritages and economic activities, which are severely jeopardized by land subsidence combined with sea-level rise. Within IGCP 663 we developed an analysis of the vulnerability of these environments to relative sea level rise (RSLR) considering an uneven land subsidence distribution that improved the assessment of vulnerability to RSLR at the regional scale. The outcomes of the analysis are available to the authorities responsible for water resources and coastal protection (Wang et al., 2012; Erkens and Stouthamer, 2020; Yang et al., 2020).

Jakarta is one of the cities mostly affected by the combination of sea-level rise and land subsidence. It has been calculated that if necessary measures are not taken, around $27 \%$ of Jakarta may be below the sea level in 2025 (Andreas et al., 2018). The project team promoted the development and launch of a "Road map for prevention and control of land subsidence in the coastal lowland of Indonesia" (Fig. 1), and co-hosted an official ceremony with the Indonesian government 

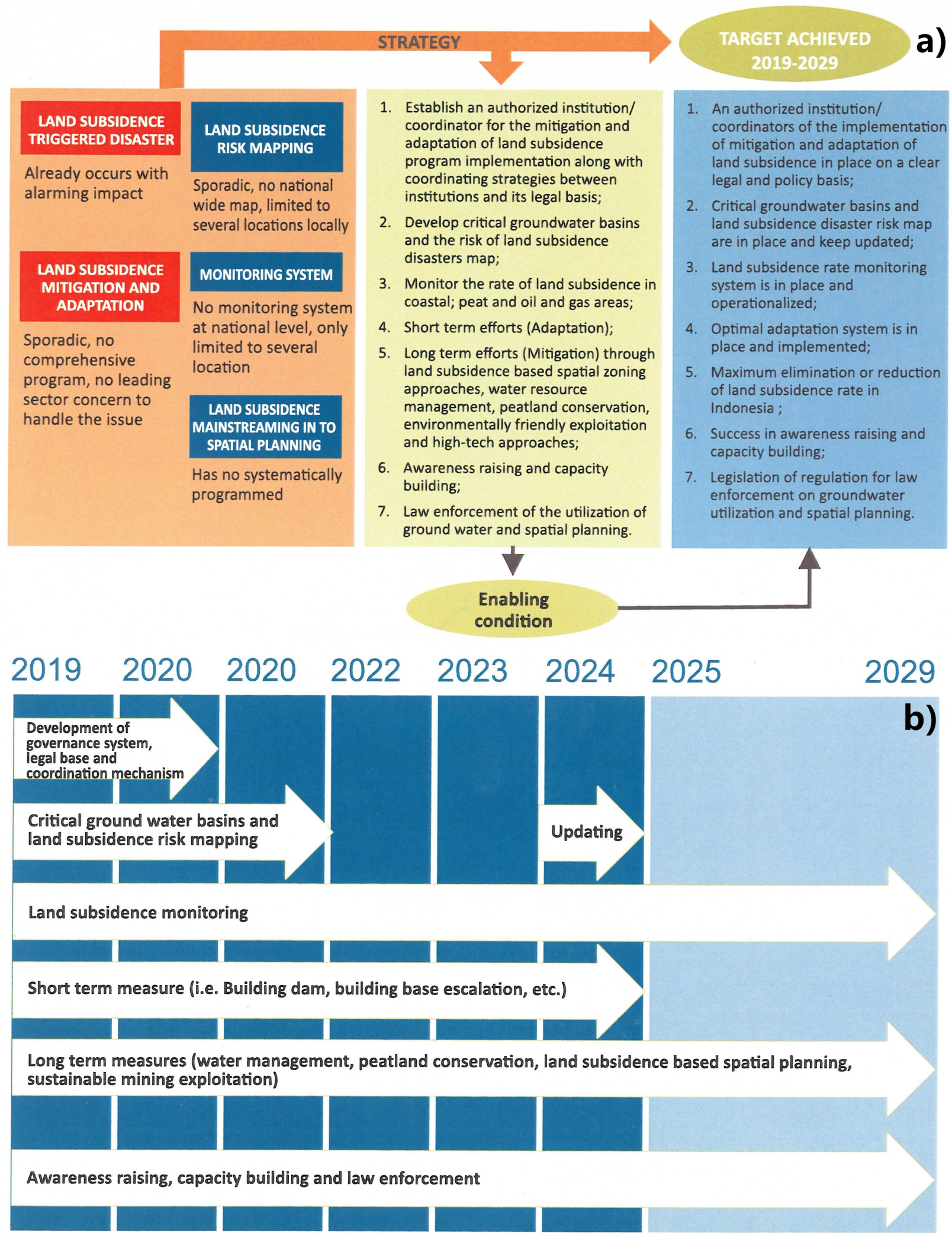

Figure 1. Road map for prevention and control of land subsidence in the coastal lowland of Indonesia: (a) general framework; (b) time frame (http://bit.ly/roadmaplandsubsidence).

for releasing the "Road map" during the 2019 project annual meeting. The Road map for mitigation and adaptation against land subsidence has been created in Indonesia and is an important first step towards the implementation of mitigation and adaptation measures. Therefore, IGCP 663 would provide support in defining the next steps and developing the workflow, as well as providing expertise and an overview of best 
practices, tracking the implementation of the road map and asking for progress to be presented during meetings.

In addition, five fascinating scientific courses have been developed for young scientists and stakeholders during the 2019 Annual Meeting of IGCP 663 in Indonesia. The course contents included several topics such as data interpretation, monitoring, simulation and prediction of land subsidence. Meanwhile, presentation opportunities were provided for young scientific and technological talents from China, Italy, Vietnam, Thailand and Pakistan to exchange and improve their research, results and ideas.

\section{Scientific Session}

\section{The Effect of Relative Sea Level Rise}

According to the historical data, most of the coastal plains in the world have faced a loss in surface elevation, despite in some of them it significantly reduced over the last decades, e.g., Shanghai-China (e.g., Wang and Jiao, 2015), Nagoya-Japan (e.g., Tosi et al., 2010), Venice-Italy (e.g., Tosi et al., 2020). While elevation loss due to land subsidence is mostly irrecoverable, global sea-level rise is increasing. Therefore, RSLR poses one of the greatest threats to transitional coastal systems around the world. Although expected sea-level rise due to climate change is the most widespread concern, locally the effect of land subsidence can be much greater. Analyses of coastal vulnerability to RSLR generally neglect or over-simplify land subsidence patterns affecting large areas. This can lead to inaccurate assessments of vulnerability that do not take account of the spatial variability of ground movements.

The case studies of the Po river delta (Italy) and the Mekong Delta (Vietnam) have been deeply discussed in the scientific session.

A reliable assessment of the vulnerability to RSLR at the Po delta (Italy) scale was developed (Da Lio and Tosi, 2019). An index-based method for assessing the vulnerability of the Po delta to RSLR under present and future SLR scenarios, which considers the spatial variability of land subsidence, was set up. The key results of this study are: 1) The overall assessment reveals that almost half of the Po delta is in a condition of critical or extreme vulnerability to RSLR in the ongoing long-series scenario, i.e. the linear trend computed on the 1875-2017 data recorded by the Trieste tide gauge is about $1.3 \mathrm{~mm} / \mathrm{yr}$, reaching more than $80 \%$ by 2025 in the future scenario, i.e., the linear trend of $3.8 \mathrm{~mm} / \mathrm{yr}$ results from the short time series 1992-2017. 2) At the entire-delta scale, the high heterogeneity of the vulnerability to RSLR reflects the combined result of the selected indices (i.e., ground displacements and hydro-morphology of the delta area). 3) Combined with a posteriori analysis of the classified thematic layers, the vulnerability assessment helps to understand the intrinsic role of the various indices, highlighting the crucial role of the uneven subsidence rates and conversely that assuming these to be uniform across the delta area is not helpful. 4) Land subsidence plays a key role in vulnerability to RSLR, subsidence rates generally being greater than the ongoing SLR trend, whether SLR is inferred from the long or the short data series, whereas subsidence and SLR rates contribute equally to RSLR in 2050. 5) More than $70 \%$ of the Po delta is characterised by moderate to extreme vulnerability to RSLR, with agricultural areas most affected.

For the Mekong Delta, Vietnam, a comparative study has been car- ried out to investigate the effect of using surface elevation data from different sources and accuracy on sea-level rise assessments (Minderhoud et al., 2019). A new surface elevation model of the Mekong Delta was created based on local surface elevation data derived from a detailed topographical map referenced to Vietnamese geodetic datum (TopoDEM). The TopoDEM was used to create new RSLR impact assessments which were compared to previous RSRL assessments made using globally available, spaceborne elevation data (SRTM). This revealed that the delta's elevation was previously overestimated by more than a meter in earlier RSLR assessments and that in reality the Mekong delta is much more exposed to RSLR that earlier assessments indicated. This demonstrated the potential implications of using global spaceborne DEMs and neglection of vertical datum conversion to a local tidal datum on RSLR impact assessments and highlights the importance of accurate, ground-truthed elevation data.

\section{Subsidence Mapping}

According to the statistical results of historical articles and documents, nearly 90 countries with land subsidence records worldwide were identified, and a country map of land subsidence distribution was drawn (Fig. 2).

In addition to the global land subsidence mapping, a more detailed map at regional and local scales has been planned to develop. One of these, i.e. the land subsidence contour cloud map of the Yangtze river delta is already completed and uploaded to the IGCP 663 project website (http://igcp.sigs.cn).

The collaborating for the global subsidence mapping with the UNESCO Land Subsidence International Initiative (LaSII) and IGCP 641 was developed, and the results showed that nineteen percent of the global population may face a high probability of subsidence (Herrera et al., 2021). More information can be found on the website of LaSII (https://www.landsubsidence-unesco.org/maps/).

\section{Monitoring and Simulation}

Some efforts have been made to enrich the monitoring and simulation methods of coastal land subsidence.

A new Multi-Anchor System for monitoring deformations of different soil layers in boreholes was developed, and its experimental application was successfully tested at Changxing Island, Shanghai. We are also carrying out research and field experiments on the use of distributed fiber sensors for recording land displacements, and further joint results are expected.

Multi-anchor-based (extensometer) monitoring is also being deployed in different parts of The Netherlands to document land surface subsidence caused due to peat oxidation and slow compaction (creep) of underlying Holocene soft-soils (van Asselen et al., 2020). Multiple sites are monitored in small areas to study the efficacy of alternative drainage-infiltration practices to reduce land subsidence. Furthermore, various geodetic techniques (spirit levelling, airborne LIDAR, InSAR) are tested at these sites in order to develop effective approaches to monitor land subsidence over extensive peat meadow areas in The Netherlands.

The data of these monitoring sites will be used to calibrate and validate land subsidence and peat-oxidation derived $\mathrm{CO}^{2}$-emission 


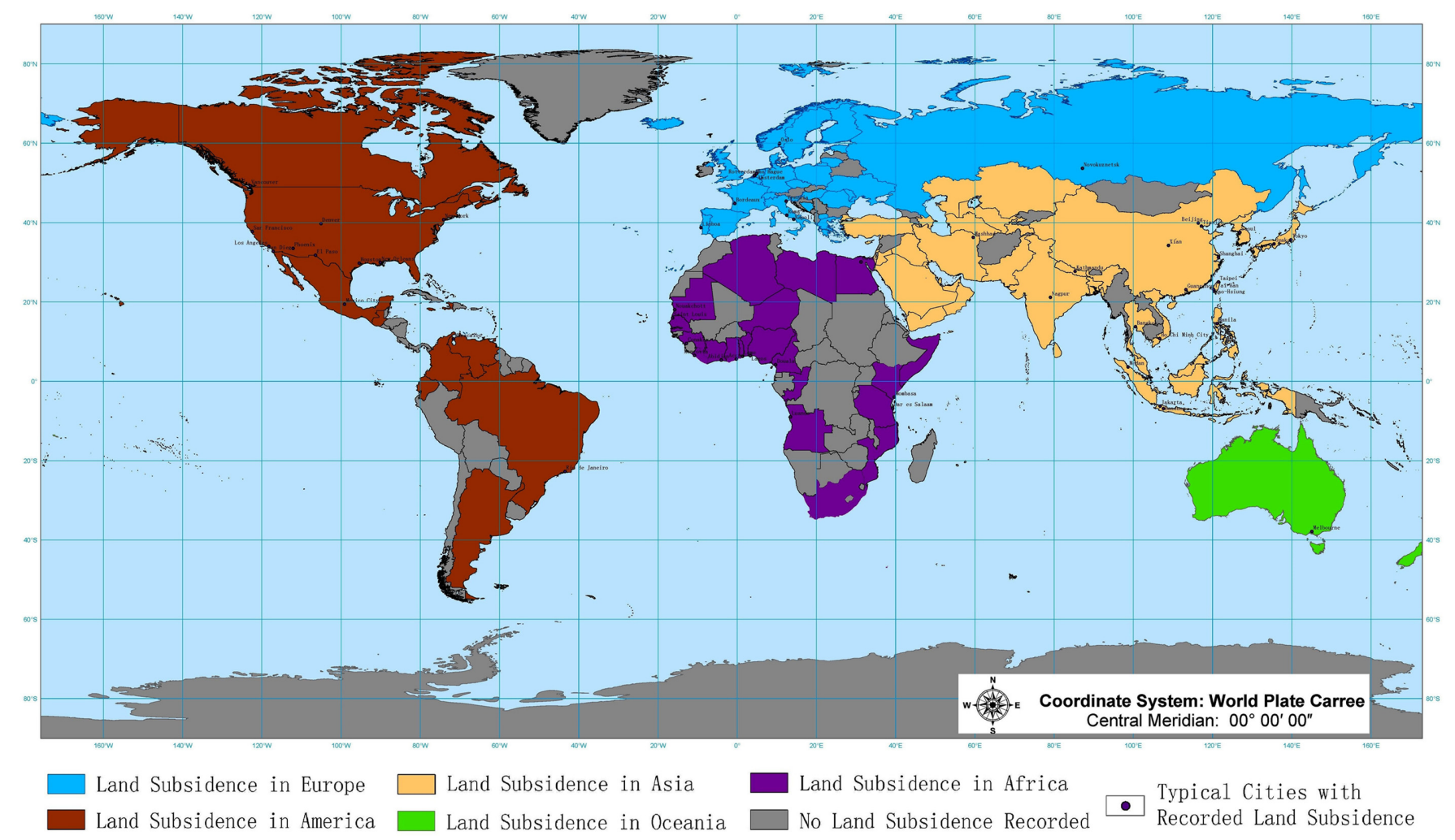

Figure 2. Map of global land subsidence distribution.

models of The Netherlands that are linked to a 3D geological model of the subsurface on a $100 \mathrm{~m}$ resolution spatial grid (Bootsma et al., 2020). To enrich simulation capabilities, isotache-based soft-soil creep formulations have been implemented in a new aquifer system compaction package SUB-CR for MODFLOW (Kooi et al., 2018) and in a 1-dimensional finite element simulator that allows study of the subsidence response to changes in dynamic water table conditions (Kooi and Erkens, 2020a). SUB-CR has, amongst others, been used to make subsidence projections for northern Jakarta (Kooi et al., 2020b) and in the Mekong delta (Minderhoud et al., 2017; 2020). The code is available for collaborative research projects. The finite-element code has been used for the city of Gouda to investigate and intercompare the effectiveness of measures that (a) prevent anomalous water table drop during a drought, (b) suppress the seasonal variability of the water table, and (c) involve a permanent rise of the mean water table.

\section{Support of Policy Making}

At present, Shanghai is in the period of slight land subsidence, but the characteristics of uneven subsidence are significant. Therefore, the main factors affecting land subsidence have changed from the unreasonable exploitation of groundwater in history to the superposition of groundwater exploitation and dewatering in deep foundation pit. In support of policy making, besides the release of the "Road map for prevention and control of land subsidence in the coastal lowland of Indonesia", the overall-process coordinated control system of groundwater exploitation and recharge and deep foundation pit dewatering (dual factors) were summarized and proposed. According to the requirements of dual factors management system, the work flow was proposed, including dynamic regulation of groundwater exploitation and dewatering, demonstration of foundation pit dewatering and water resources, information sharing of land subsidence, data collection and exchange of project completion, law enforcement of monitoring facility damage et al. The dual factor management system is gradually put into use by the local government in Shanghai.

For the Vietnamese Mekong Deltafuture subsidence and the implications for flood exposure for different groundwater extraction scenarios were quantified by using a delta-wide 3D hydrogeological model (iMOD-SUB-CR, Minderhoud et al., 2017). Scenarios range from immediately stopping groundwater extraction to doubling of the present extraction rate. Its effects on subsidence and flood risk were visually presented for the years 2030, 2050, 2080 and 2100 (Minderhoud et al., 2020). These process-based scenarios quantifications using numerical models enable policymakers to make well-informed decisions regarding groundwater extraction and land subsidence.

\section{Field Trips}

There are at least 132 districts in 21 provinces in Indonesia with currently indicated land subsidence. We investigated 4 typical sites severely affected by historical land subsidence. One of these is Muara Baru, where $1.4 \mathrm{~m}$ of ground elevation was lost from 2004 to 2015 (Fig. 3). 


\section{Stop 1: Muara Baru, 66'10"S 106 $48^{\prime} 3^{\prime \prime} E$ (WGS1984)}

The Deep Pile Bench Mark (DPBM) was destroyed by land subsidence (Fig. 4a), and a residential block was abandoned due to permanent coastal flooding (Fig. 4b).

The concrete plinth of a DPBM, which was used to measure the displacement of deep rock strata, was damaged and separated due to differential subsidence between shallow soft soil and bedrock (Fig. 4a). The DPBM was installed in 2009 anchored at a depth of 300 meter. In 10 years' time, $\sim 80 \mathrm{~cm}$ of differential subsidence occurred between 0 and 300 meters. On top of that the benchmark itself also subsided $\sim 40 \mathrm{~cm}$ (GPS measurement), which represents the subsidence that happened deeper than 300 meters. In total the location of benchmark experienced $\sim 120 \mathrm{~cm}$ subsidence since 2009 . In addition, due to the impact of land subsidence, this seaside residential block was inundated with seawater from time to time, and people in the houses had/have to go in and out by boat (Fig. 4b).

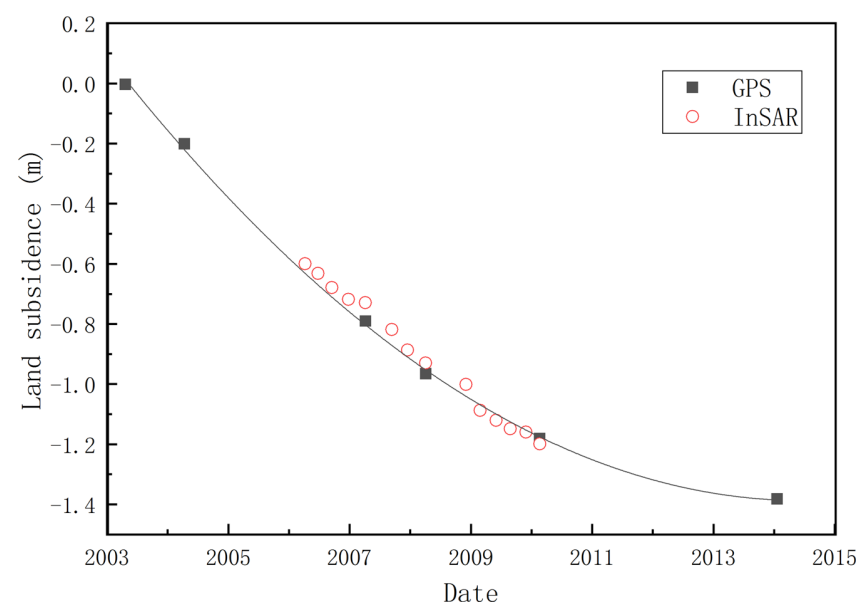

Figure 3. Average local land subsidence monitored by InSAR and GPS in Jakarta.
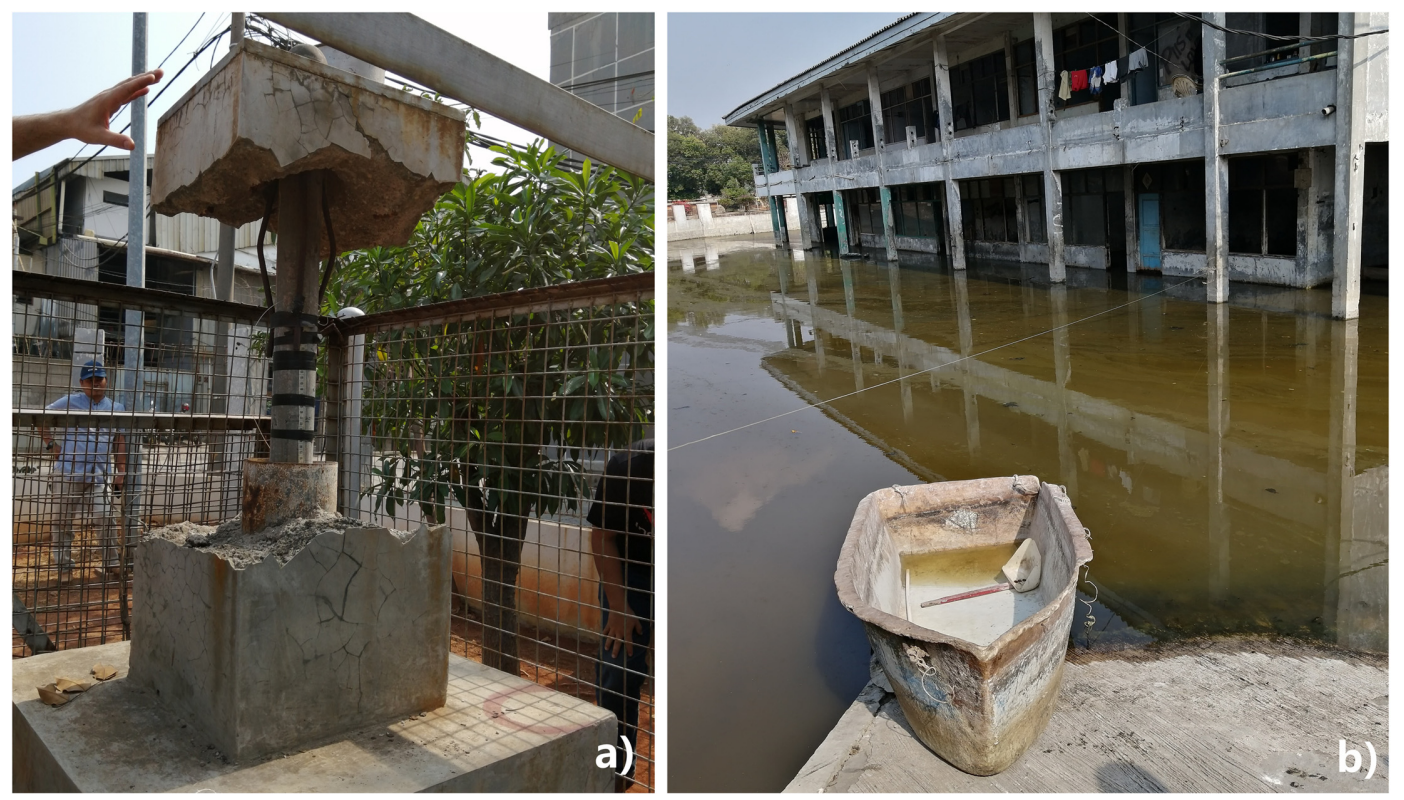

Figure 4. Some local remains of land subsidence: (a) damaged deep pile benchmark installed in 2009; (b) flooded apartment complex.
Stop 2: Pluit Pumping Station, 606'32"S 106 $47^{\prime} 51^{\prime \prime} E$
(WGS1984)

The Old Sea Dyke and the Newest Sea Dyke was used to protect land from coastal flooding due to the land subsidence (Fig. 5a). We can see that when the flood season comes, the high tide is already higher than the levees that have been built, and the houses of coastal residents are often flooded (Fig. 5b). Because of the rapid increase of RSLR, the design of the seawall has been revised, before its construction is completed, to build a higher one. The use of a pumping station is also necessary to keep the water level in the mainland lower than the sea level, especially when experiencing sea level events higher than usual.

\section{Stop 3: Kamal Pumping Station, 6 ${ }^{\circ} 6^{\prime 25} 5^{\prime \prime} \mathrm{S} 106^{\circ} 43^{\prime} 33^{\prime \prime} \mathrm{E}$ (WGS1984)}

It can be seen clearly that sea level is $2 \mathrm{~m}$ higher compared to river water level. At this location we also see a drowning road due to land subsidence and coastal flooding.

In addition, the local surface water pollution is also very serious. There are not enough alternative water sources, so that groundwater is still an important resource for local people.

\section{Stop 4: Green Bay Area, 66'29'"S 106'46'49"' E(WGS1984)}

Indonesian coastal cities such as Jakarta, Semarang, Demak, Pekalongan and Surabaya experience serious land subsidence.

The Green Bay Mall area is still sinking $80 \sim 100 \mathrm{~mm} /$ year at the moment (Fig. 7). The coastal peatland region also experiences land subsidence, where the average land subsidence can reach 10$200 \mathrm{~mm} / \mathrm{year}$, and at the same time there is a sea level rise with an average of $4 \sim 10 \mathrm{~mm}$ per year. As a result, coastal cities suffer tidal flooding. 


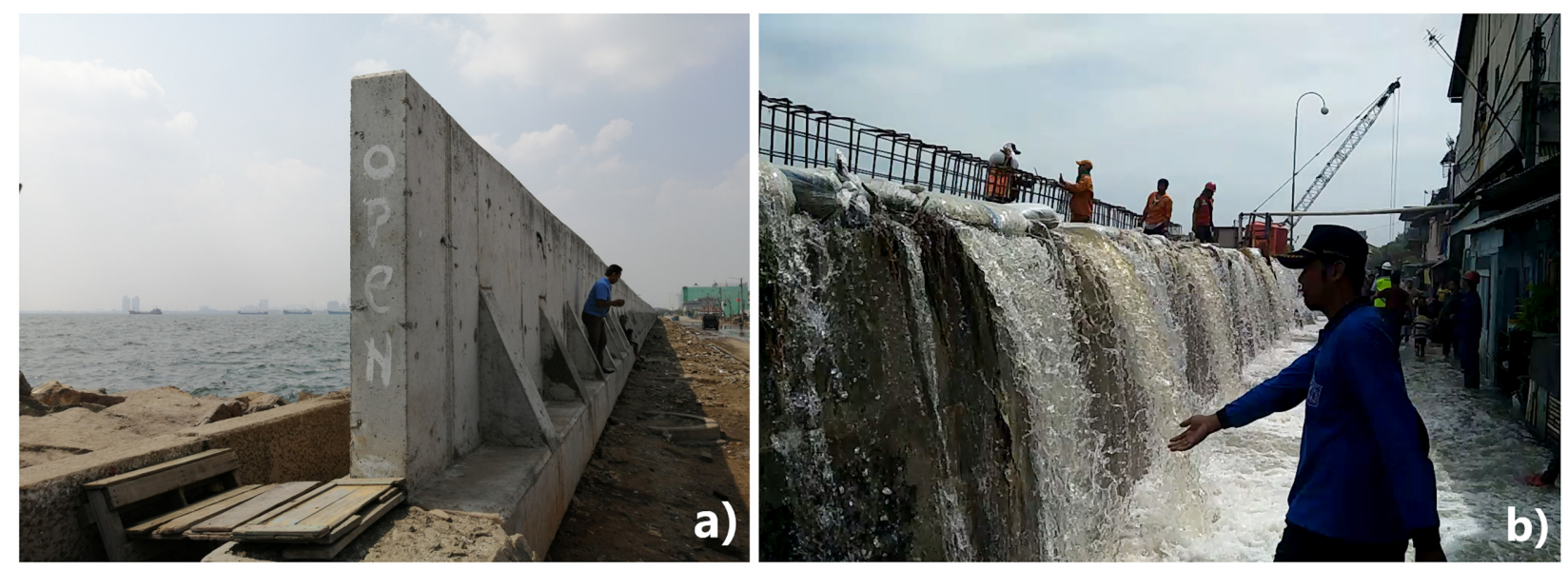

Figure 5. Sea Dyke in Jakarta: (a) the newest sea dyke; (b) the flood overflowed the dam.
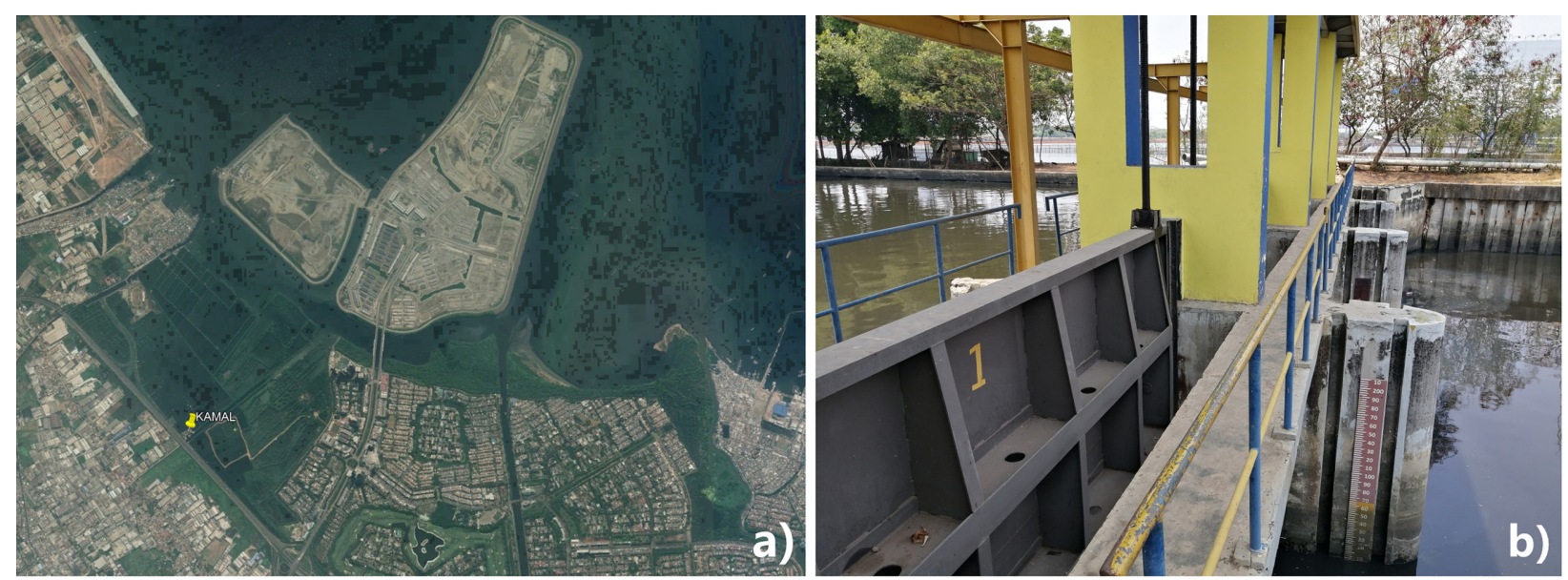

Figure 6. KAMAL pumping station: (a) satellite image of the Jakarta coastal lowland area; (b) difference between sea level (left) and water level of the inland river (right).

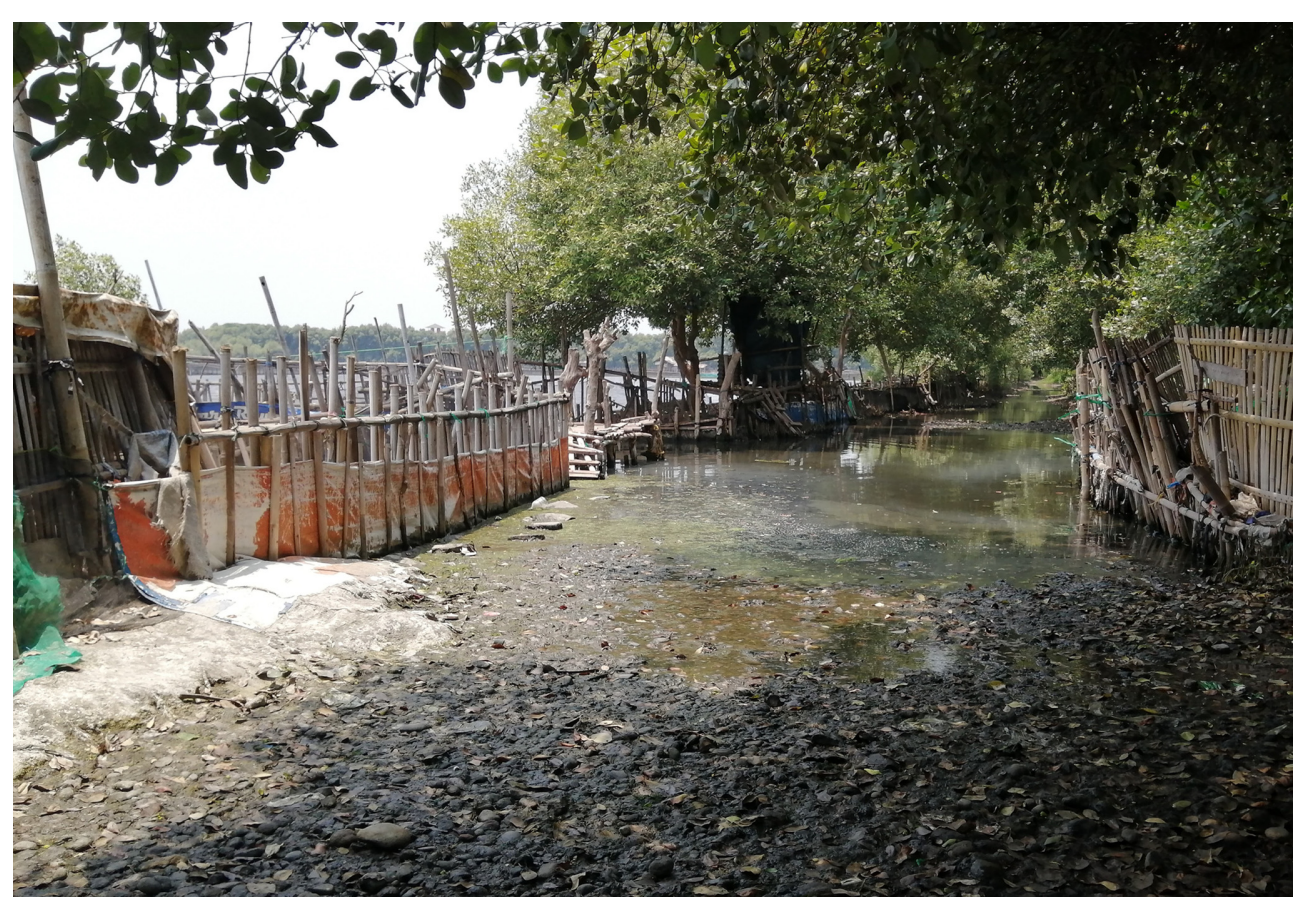

Figure 7. Green Bay Mall area in Jakarta. 


\section{Summary and Resolutions}

During the second international workshop held in 2019 in Jakarta, Indonesia, the activities carried out under the umbrella of the IGCP Project 663 were presented. They focused on the discussion of the main scientific results, a series of technical teaching and training, dissemination, and a field trip. In addition, delegates of the UNESCO LaSII participated and the Indonesian government held an official release ceremony of the "Road map for prevention and control of land subsidence in the coastal lowland of Indonesia".

The promotion of the scientific and technological cooperation on land subsidence worldwide, specifically in underdeveloped areas, is the key objective of the IGCP Project 663. This includes to provide more opportunities to young scientific and technological talents for improving their coastal subsidence knowledge in order to form a new generation of scientists and practitioners with expertise in impact assessment, monitoring and prevention technologies. In particular, the IGCP Project 663 funded eight young professionals, from China, Vietnam, Italy, Thailand and Pakistan to participate the 2019 IM2LSC annual workshop in Jakarta, and provided them the chances to give presentations and communicate with senior experts during the special sections.

\section{Acknowledgements}

This is a contribution of the IGCP-663 project of the IUGS and UNESCO. The authors appreciate the financial support provided by the Shanghai Science and Technology Commission (No. 20DZ1201200) for this work. We also want to thank Heri Andreas and Dhota Pradipta for organizing the field trips.

\section{References}

Andreas, H., Abidin, H.Z., Sarsito, D.A., and Pradipta, D., 2018. Adaptation of 'Early Climate Change Disaster' to the Northern Coast of Java Island Indonesia. Engineering Journal, v. 22, pp. 207-219, doi:10.4186/ ej.2018.22.3.207

Bootsma, H., Kooi, H., and Erkens, G., 2020. Atlantis, a tool for producing national predictive land subsidence maps of the Netherlands. Proceedings of the International Association of Hydrological Sciences, v. 382, pp. 415-420, doi:10.5194/piahs-382-415-2020

Da Lio, C., and Tosi, L., 2019. Vulnerability to relative sea-level rise in the Po river delta (Italy). Estuarine, Coastal and Shelf Science, v. 228, doi:10.1016/j.ecss.2019.106379

Erkens, G., and Stouthamer, E., 2020. The 6M approach to land subsidence. Proceedings of the International Association of Hydrological Sciences, v. 382, pp. 733-740. doi:10.5194/piahs-382-733-2020

Herrera-García, G., Ezquerro, P., Tomás, R., Béjar-Pizarro, M., López-Vinielles, J., Rossi, M., Mateos, R.M., Carreón-Freyre, D., Lambert, J., Teatini, P., Cabral-Cano, E., Erkens, G., Galloway, D., Hung, W.C., Kakar, N., Sneed, M., Tosi, L., Wang, H.M., and Ye, S.J., 2021. Mapping the global threat of land subsidence. Science, v. 371, pp. 34-36, doi:10.1126/sci- ence.abb8549

Kooi, H., Bakr, M., de Lange, G., den Haan, E., and Erkens, G., 2018. User guide to SUB-CR; a MODFLOW package for land subsidence and aquifer system compaction that includes creep, Deltares internal report 11202275008, available at: http://publications.deltares.nl/11202275_008.pdf.

Kooi, H., and Erkens, G., 2020a. Creep consolidation in land subsidence modelling; integrating geotechnical and hydrological approaches in a new MODFLOW package (SUB-CR). Proceedings of the International Association of Hydrological Sciences, v. 382, pp. 499-503, doi:10.5194/piahs382-499-2020

Kooi, H., and Erkens, G., 2020b. Modelling subsidence due to Holocene soft-sediment deformation in the Netherlands under dynamic water table conditions. Proceedings of the International Association of Hydrological Sciences, v. 382, pp. 493-498, doi:10.5194/piahs-382-493-2020

Minderhoud, P.S.J, Middelkoop, H., Erkens, G., and Stouthamer, E., 2020. Groundwater extraction may drown mega-delta: projections of extractioninduced subsidence and elevation of the Mekong delta for the 21th century. Environmental Research Communications, doi:10.1088/2515-7620/ ab5e 21

Minderhoud, P. S. J., Coumou, L., Erkens, G., Middelkoop, H., and Stouthamer, E., 2019. Mekong delta much lower than previously assumed in sea-level rise impact assessments. Nature Communications, v. 10, doi:10.1038/s41467-019-11602-1

Minderhoud, P.S.J., Erkens, G., Pham Van, H., Bui Tran, V., Erban, L.E., Kooi, H., and Stouthamer, E., 2017. Impacts of 25 years of groundwater extraction on subsidence in the Mekong delta, Vietnam. Environmental Research Letters, v. 12, doi:10.1088/1748-9326/aa7146

Tosi, L., Da Lio, C., Donnici, S., Strozzi, T., and Teatini, P., 2020. Vulnerability of Venice's coastland to relative sea-level rise. Proceedings of the International Association of Hydrological Sciences, v. 382, pp. 689695, doi:10.5194/piahs-382-689-2020

Tosi, L., Teatini, P., Strozzi, T., Carbognin, L., Brancolini, G., and Rizzetto, F., 2010. Ground Surface Dynamics in the Northern Adriatic Coastland over the Last Two Decades. Rendiconti Lincei. Scienze Fisiche E Naturali, v. 21, pp. 115-129, doi:10.1007/s12210-010-0084-2

Van Asselen, Erkens, G., and de Graaf, F., 2020. Monitoring shallow subsidence in cultivated peatlands. Proceedings of the International Association of Hydrological Sciences, v. 382, pp. 189-194, doi:10.5194/piahs382-189-2020

Wang, H.M., and Jiao, X., 2015. Control Strategy of Land Subsidence in Shanghai Under Sea-Level Rise. Climate Change Research, v. 11, pp. 256-262 (in Chinese with English abstract), doi:10.3969/j.issn.16731719.2015.04.004

Wang, J., Gao, W., Xu, S., and Yu, L., 2012. Evaluation of the combined risk of sea level rise, land subsidence, and storm surges on the coastal areas of Shanghai, China. Climatic Change, v. 115, pp. 537-558, doi:10.1007/ s10584-012-0468-7

Yan, X.X., Yang, T.L., Xu, Y., Tosi, L., Stouthamer, E., Andreas, H., Minderhoud, P., Anirut, L., Hanssen, R., Eekens, G., Teatini, P., Lin, J.X., Bonì, R., Jarinya, C., Huang, X.L., Da Lio, C., Meisina, C., and Zucca, F., 2020. Advances and Practices on the Research, Prevention and Control of Land Subsidence in Coastal Cities. Acta Geologica Sinica (English Edition), v. 94, pp. 162-175, doi:10.1111/1755-6724.14403

Yang, T.L., Yan, X.X., Huang, X.L., and Wu, J.Z., 2020. Integrated management of groundwater exploitation and recharge in Shanghai based on land subsidence control. Proceedings of the International Association of Hydrological Sciences, v. 382, pp. 831-836, doi:10.5194/piahs-382831-2020 


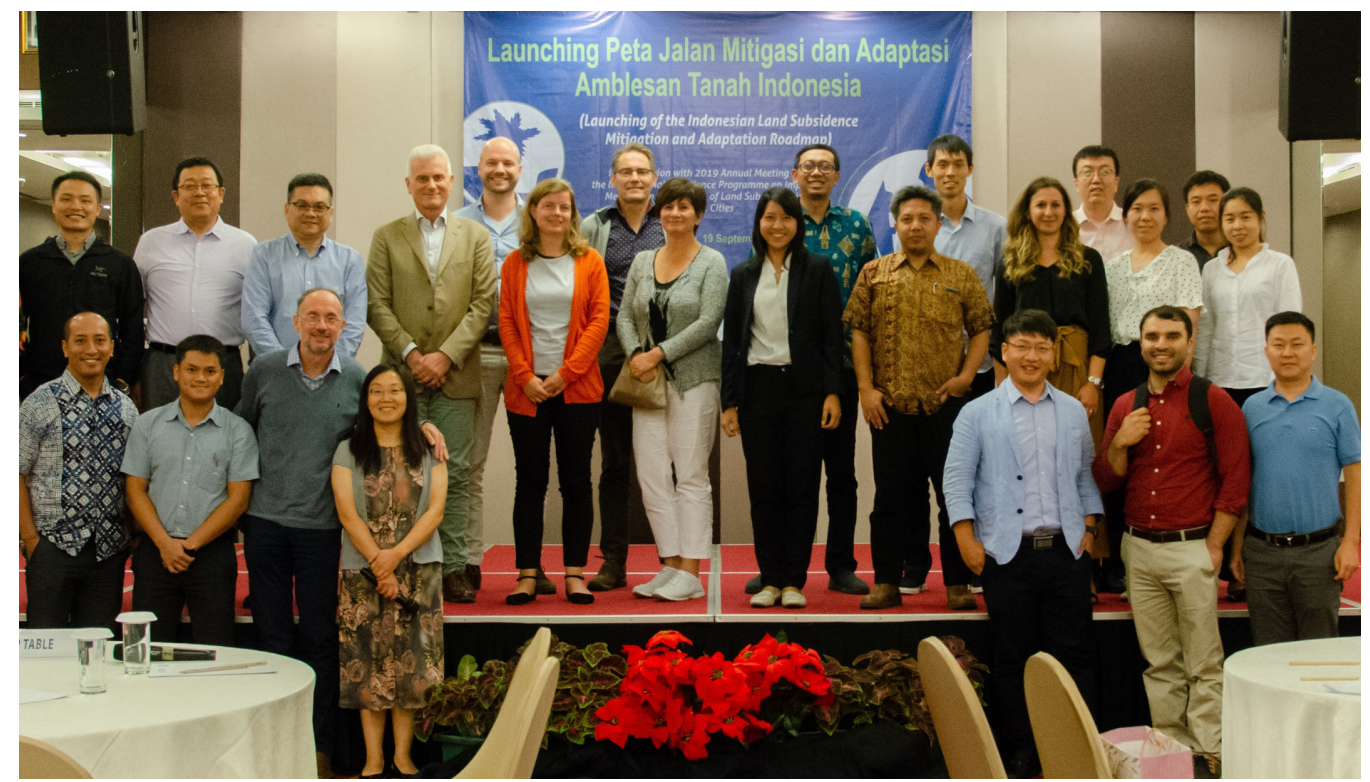

Xuexin Yan (second row, third one) is the Chief Engineer of Shanghai Institute of Geological Survey, and Director of the Key Laboratory for Monitoring and Prevention of Land Subsidence, Ministry of Natural Resources of China. Since 1982, he has been engaging in geological survey and researches on hydrology, urban geology, environmental geology, etc. He is now interested in the surveys and evaluation of environmental geology, and the control of geological disasters.

$\boldsymbol{Y a n} \boldsymbol{X u}$ (third row, forth one) holds a PhD in geological engineering and works at Shanghai Institute of Geological Survey since 2016. His research is mainly focused on engineering geology, environmental geology and the control of geological disasters in soft soil area.

Tianliang Yang (first row, first one from right) holds a $\mathrm{PhD}$ in geological engineering. He has long-standing interests in the research of land subsidence monitoring, prevention and control. Dr. Yang achieved the Outstanding Young Scientists and Technicians of the Ministry of Natural Resources of China. He has written more than 30 publications in peer reviewed international journals.

Luigi Tosi (second row, forth one) is Research Director at the National Research Council - Institute of Geosciences and Earth Resources in Padova, Italy. Dr. Tosi's research interests focus on coastal hydrogeology, particularly natural and anthropogenic land subsidence, relative sea level rise and saltwater intrusion. His studies also include Late Quaternary geology, geological and geomorphological mapping of coastal areas and underwater (scuba diving) hydro-geomorphology.

Esther Stouthamer (second row, fifth one) is associate professor in Physical Geography at the Global Change Geomorphology group, Department of Physical Geography, Utrecht University. Her fields of expertise are Quaternary geology, delta evolution, subsurface architecture and characterization, subsidence, fluvial and coastal geomorphology.

Philip Minderhoud (third row, first one) is assistant professor in the Soil Geography and Landscape group at Wageningen University, EU MarieCurie research fellow at the University of Padova and connected as advisor to Deltares. His research focuses fundamental understanding of processes and drivers of deltaic subsidence and developing numerical capacities to increase spatial-temporal assessments of current and projections of future deltaic subsidence.

Pietro Teatini (first row, third one) is associate professor in Hydrology and Hydraulic Engineering at UniPD. He has more than 130 papers in peer reviewed international journals (Google Scholar H-index $=43$ ). He is chair of the UNESCO International Initiative on Land Subsidence. His scientific interests include the characterization of the processes in the field of environmental geomechanics (e.g., land subsidence, induced seismicity, evolution of Holocene landforms, peatland oxidation).

Henk Kooi (third row, second one) is senior advisor/researcher at Deltares. Henk has an MSc in geophysics, a PhD in tectonics, held several postdoctoral positions, among which a Killam-postdoctoral fellowship at Dalhousie University, Halifax, Canada. 2000-2015 Henk was assistant and associate professor in hydrogeology at VU University Amsterdam. At Deltares Henk focuses on fundamental and applied aspects of groundwater hydrology and land subsidence.

Heri Andreas (second row, forth one from right) is lecturer in Institute of Technology Bandung. He finished his doctoral degree in early 2013 . His specialties are in satellite geodesy and advance positioning. He is studying and implementing knowledge and techniques of satellite geodesy (e.g. GPS and GNSS) and advance positioning for several subjects including studying land subsidence since 1997.

Dhota Pradipta (third row, third one) was received Doctoral Degree in Engineering Geodesy about GNSS technology. He is a Professor assistant and responsible for educating students about GNSS applications, including data assessment, processing, analysis, and QA/QC. He is an researcher working alongside the Geodesy Research Group at Bandung Institute of Technology.

Sandra Donnici (second row, sixth one), $\mathrm{PhD}$ in environmental sciences, is research scientist at the National Research Council - Institute of Geosciences and Earth Resources in Padova, Italy. Her fields of interest include Quaternary stratigraphy, evolution of coastal areas, micropaleontology and paleoenvironmental reconstruction.

Roberta Bonì (second row, third one from right) is research fellow in Engineering Geology at the Dept. of Earth and Environmental Sciences, Pavia University (Italy). Her fields of expertise are geological interpretation of satellite radar interferometric data for natural and human-induced hazards such as land subsidence; subsoil engineering geological models to support geohazard assessment; modeling of ground motion due to groundwater level changes. 